\title{
Perbedaan Pola Asuh dan Tingkat Kecukupan Zat Gizi pada Balita Stunting dan Non-Stunting di Wilayah Pesisir Kabupaten Probolinggo
}

\section{Differences in Parenting and Nutrient Adequacy Level on Stunting and Non- Stunting Toddlers in the Coastal Area Probolinggo District}

Mita Femidio*, Lailatul Muniroh

\begin{abstract}
ABSTRAK
Latar Belakang: Stunting masih terjadi di daerah pesisir, padahal masyarakat tersebut memiliki peluang lebih besar mengkonsumsi ikan yang kaya protein sehingga dapat mencegah stunting.

Tujuan: Menganalisis perbedaan pola asuh dan tingkat kecukupan zat gizi pada balita stunting dan non-stunting di wilayah pesisir Kabupaten Probolinggo.

Metode: Desain studi yang digunakan adalah case-control. Penelitian dilakukan di desa pesisir yaitu Desa Pajurangan, wilayah kerja Puskesmas Gending. Total sampel adalah 46 subjek balita berusia 24-59 bulan, terbagi menjadi 23 balita kelompok stunting dan 23 balita kelompok non-stunting. Pengambilan sampel menggunakan metode simple random sampling dari total populasi 194 balita. Pengumpulan data meliputi pengukuran tinggi badan balita dengan mikrotoa oleh peneliti serta wawancara kuesioner pola asuh dan Semi Quantitative Food Frequency Questionnare (SQ-FFQ). Data dianalisis menggunakan uji Chi-Square dengan melihat Odds Ratio (OR).

Hasil: 60,9\% kelompok stunting memiliki pola asuh pemberian makan kategori sedang, sedangkan pola asuh perawatan kesehatan dasar kategori baik (91,3\%). Tingkat Kecukupan energi (60,9\%), protein (65,2\%) dan seng (56,5\%) pada kelompok stunting kategori kurang, sedangkan vitamin A kategori cukup $(65,2 \%)$. Terdapat perbedaan pola asuh pemberian makan $(p=0,002 ; O R=10,37 ; 95 \% C l=2,374-45,301)$, tingkat kecukupan energi $(p=0,037 ; O R=4,407 ; 95 \% C l=1,26-15,414)$, protein $(p=0,001 ; O R=12,5 ; 95 \% \mathrm{Cl}=2,828-55,254)$ dan seng $(p=0,015 ; O R=6,175 ; 95 \% \mathrm{Cl}=1,589-23,993)$ pada balita stunting dan nonstunting. Tidak terdapat perbedaan pola asuh perawatan kesehatan dasar $(p=0,662)$ dan tingkat kecukupan vitamin $A$ $(\mathrm{p}=0,314)$ pada balita stunting dan non-stunting.

Kesimpulan: Pola asuh pemberian makan serta tingkat kecukupan energi, protein dan seng yang kurang berisiko lebih besar balitanya mengalami stunting dibanding kelompok yang cukup.
\end{abstract}

Kata kunci: Stunting, pola asuh, tingkat kecukupan zat gizi

\section{ABSTRACT}

Background: Stunting was still found in coastal areas, whereas people there had greater opportunities to consume fish which is contain high animal protein to prevent stunting.

Objectives: To analyze differences in parenting and nutrient adequacy level on stunting and non-stunting toddlers in the coastal area of Probolinggo District.

Methods: This study was a case-control design, which conducted in the village of Pajurangan included Puskesmas Gending. The total sample were 46 toddlers (24-59 months old) divided into cases group (stunting) and control group (non-stunting) with each of group 23 toddlers, that chosen by simple random sampling method from 194 population of toddlers. Data collection included toddler height measurements with microtoise by researchers as well as the questionnaires parenting and SQ-FFQ. Data were analyzed using the Chi-Square test by Odds Ratio (OR).

Results: 60.9\% stunting group have parenting feeding medium category, but parenting basic health care have good parenting category (91.3\%). Most of adequacy level of energy (60.9\%), protein (65.2\%) and zinc (56.5\%) in stunting group were less category, whereas vitamin A was enough category (65.2\%). Therefore, there were differences in parenting feeding $(p=0.002 ; O R=10.37 ; 95 \% \mathrm{Cl}=2.374-45.301)$ and energy adequacy level $(p=0.037 ; 0 R=4.407 ; 95 \% \mathrm{Cl}=1.26-15.414)$, protein $(p=0.001 ; O R=12.5 ; 95 \% C l=2.828-55.254)$ and $\operatorname{zinc}(p=0.015 ; O R=6.175 ; 95 \% C l=1.589-23.993)$ on stunting and non-stunting toddlers. However, there were no differences in parenting basic health care $(p=0.662)$ and adequacy of vitamin $A(p=0.314)$ on stunting and non-stunting toddlers.

Conclusions: Improper parenting and toddler with inadequate levels of energy, protein and zinc had greater risk of stunting compared to toddlers suffered enough.

(C)2020. Femidio dan Muniroh. Open access under CC BY - SA license.

Received: 09-09-2019, Accepted: 18-10-2019, Published online: 15-03-2020.

doi: 10.20473/amnt. v4i1.2020. 49-57 Joinly Published by IAGIKMI \& Universitas Airlangga 


\title{
Keywords:Stunting, parenting, nutritional adequacy level
}

\author{
*Koresponden: \\ Mita Femidio \\ mita.femidio-2015@fkm.unair.ac.id \\ Departemen Gizi Kesehatan, Fakultas Kesehatan Masyarakat, Universitas Airlangga
}

\section{PENDAHULUAN}

Masa balita merupakan periode penting dalam proses pertumbuhan dan perkembangan, terjadi peningkatan secara pesat sehingga disebut periode emas dalam siklus kehidupan. Tumbuh kembang balita tentunya membutuhkan asupan gizi yang cukup dan sesuai agar tidak terjadi permasalahan gizi ${ }^{1}$. Buruknya kualitas asupan gizi pada balita dalam jangka panjang akan menimbulkan permasalahan serius yaitu stunting.

Stunting merupakan indikasi masalah gizi yang bersifat kronis akibat dari kondisi tertentu yang berlangsung lama seperti kemiskinan, perilaku hidup tidak sehat dan asupan makan yang kurang dalam jangka waktu lama sehingga mengakibatkan anak menjadi pendek (stunting) ${ }^{2}$. Dampak jangka pendek yang ditimbulkan dari kejadian stunting yaitu perkembangan otak terganggu sehingga mempengaruhi kecerdasan balita. Selain itu pertumbuhan fisik dan metabolisme dalam tubuh juga dapat terganggu. Dampak jangka panjang kejadian stunting yaitu dapat menimbulkan penurunan kemampuan kognitif dan prestasi belajar serta penurunan imunitasi tubuh sehingga anak mudah sakit. Balita dapat memiliki risiko tinggi mengalami penyakit tidak menularhingga disabilitas pada usia lanjut ${ }^{3}$.

Kejadian stunting pada balita disebabkan oleh pola asuh ibu dan tingkat kecukupan zat gizi balita yang kurang. Pola asuh ibu dapat dibedakan menjadi dua, pola asuh pemberian makan dan pola asuh perawatan kesehatan dasar. Pola asuh pemberian makan berkaitan dengan pemilihan dan cara makan. Pola asuh perawatan kesehatan dasar berkaitan denganperhatian ibu terhadap kesehatan anak ${ }^{4}$.Perilaku ibu dalam menyusui atau memberi makan dengan makanan yang sehat dan bergizi serta mengontrol besar porsi yang dihabiskan dapat meningkatkan status gizi anak. Hal tersebut menunjukkan ibu yang memberikan perhatian lebih terhadap anaknya dalam hal pemberian makan akan mempengaruhi status gizi anak menjadi lebih baik, sedangkan ibu yang kurang memberikan perhatian pada pemberian makan dapat menimbulkan masalah gizi. Begitu juga dengan pola asuh perawatan kesehatan dasar, ibu yang menjaga kebersihan anak dengan baik memiliki anak dengan tinggi badan normal dibanding yang kurang menjaga kebersihan anak ${ }^{5}$.

Selain pola asuh, tingkat kecukupan zat gizi yang kurang dapat mempengaruhi kejadian stunting balita. Beberapa zat gizi yang berperan dalam kejadian stunting adalah energi, protein, seng dan vitamin A. Energi berperan penting dalam proses pertumbuhan untuk pembentukan jaringan-jaringan baru serta metabolisme di dalam sel, sehingga kekurangan energi dapat menghambat pertumbuhan ${ }^{6}$. Begitu pula dengan tingkat asupan protein ${ }^{7}$, seng ${ }^{8}$ dan vitamin $A^{9}$, karena asupan makronutrien dan mikronutrien tersebut mempengaruhi pertumbuhan linear anak.

Beberapa faktor tersebut berimplikasi dengan kejadian stunting. Prevalensi stunting di Indonesia pada tahun 2013 sebesar 37,2\%, kemudian mengalami penurunan pada tahun 2018 menjadi $30,8 \%{ }^{10,11}$. Walaupun mengalami penurunan, stunting masih menjadi masalah kesehatan masyarakat yang perlu ditangani karena prevalensinya melebihi $20 \%{ }^{12}$. Salah satu daerah provinsi yang menjadi sorotan masalah gizi stunting adalah Jawa Timur, terdapat perubahan peningkatan prevalensi stunting dari tahun 2016 ke tahun 2017 secara bertutur-turut sebesar $26,1 \%$ menjadi $26,7 \%{ }^{13,14}$. Kabupaten Probolinggo memiliki prevalensistunting yang cukup tinggi yaitu $32 \%{ }^{15}$, prevalensi ini masih berada di atas rata-rata angka nasional. Puskesmas Gending merupakan puskesmas urutan kedua dengan prevalensi stunting tertinggi di Kabupaten Probolinggo pada tahun 2018 setelah Puskesmas Sumber. Permasalahan stunting juga dipengaruhi oleh keadaan topografi seperti wilayah pesisir. Masyarakat yang tinggal di wilayah pesisir seharusnya memiliki peluang lebih besar mengkonsumsi makanan hewani tinggi protein seperti ikan karena akses dan ketersediaannya yang cukup banyak, sehingga permasalahan gizi seperti stunting tidak banyak terjadi ${ }^{16}$. Kenyataannya, Desa Pajurangan merupakan desa pesisir yang termasuk wilayah kerja Puskesmas Gending dengan prevalensi kejadian stunting sebesar $42 \%{ }^{15,17}$. Penelitian Rahmayana dkk pada balita usia 24-59 bulan di wilayah pesisir Kelurahan Barombong Kecamatan Tamalate Kota Makassar juga menunjukkan bahwa 54,8\% mengalami masalah stunting ${ }^{5}$. Kejadian stunting di wilayah pesisir ini perlu diidentifikasi dan dianalisis faktor penyebabnya, sehingga dapat memberikan gambaran perbedaan dua kelompok dan masukan bagi Dinas Kesehatan, puskesmas dan masyarakat setempat. Tujuan penelitian adalah menganalisis perbedaan pola asuh ibu dan tingkat kecukupan zat gizi pada balita stunting dan nonstunting di wilayah pesisir Kabupaten Probolinggo. 


\section{METODE}

Jenis penelitian menggunakan observasional analitik dengan desain case-control. Populasi penelitian ini adalah seluruh balita stunting dan non stunting yang berada di Desa Pajurangan Kecamatan Gending Kabupaten Probolinggo, didapatkan melalui data sekunder Puskesmas Gending Kabupaten Probolinggo. Kelompok kasus pada penelitian ini adalah balita stunting (TB/U < -2 SD dan < -3 SD) di Desa Pajurangan Kabupaten Probolinggo sebanyak 83 balita. Kelompok kontrol adalah balita non stunting (TB/U -2 sampai dengan 2 SD) di Desa Pajurangan Kabupaten Probolinggo sebanyak 111 balita $^{17}$. Sampel ditentukan dengan menggunakan rumus Lemeshow, sehingga didapatkan sampel untuk masing-masing kelompok sebanyak 23 balita dan total sampel 46 balita $^{18}$. Pengambilan sampel menggunakan simple random sampling. Sampel yang diteliti adalah balita dengan kriteria inklusi meliputi memiliki buku KMS dan tidak sedang sakit kronis seperti Tuberculosis, sedangkan kriteria eksklusi yaitu menderita cacat bawaan seperti Hidrosefalus dan sindrom tertentu. Penelitian ini melibatkan responden dalam wawancara kuesioner. Adapun responden dalam penelitian ini memiliki kriteria inklusi merupakan ibu kandung dari balita yang dijadikan sampel dan bersedia mengikuti penelitian serta mengisi formulir persetujuan. Kriteria eksklusi responden adalah pengasuh selain ibu kandung dari balita yang dijadikan sampel.

Data yang digunakan dalam penelitian adalah data primer dan sekunder. Data primer didapatkan dari hasil wawancara langsung dengan responden menggunakan kuesioner, terdiri dari kuesioner karakteristik responden (usia dan pendidikan), karakteristik keluarga (pekerjaan dan pendapatan keluarga), karakteristik balita (usia dan jenis kelamin), pola asuh pemberian makan, pola asuh perawatan kesehatan dasar dan Semi Quantitative Food Frequency Questionaire balita (SQ-FFQ). Selain itu dilakukan pengukuran tinggi badan balita oleh peneliti dengan menggunakan alat ukur microtoise. Pendidikan ibu diklasifikasikan menjadi dasar, menengah dan tinggi. Pendapatan keluarga menggunakan kuesioner dengan jawaban terbuka kemudian diklasifikasikan berdasarkan kuartil menjadi kuartil 1, kuartil 2, kuartil 3 dan kuartil 4. Adapun pendapatan keluarga kemudian diklasifikasikan berdasarkan Upah Minimum Kota/Kabupaten (UMK) Kabupaten Probolinggo menjadi kurang dari UMK dan lebih dari UMK Kabupaten Probolinggo. Kuesioner pola asuh diadaptasi dari penelitian sebelumnya yaitu Adelina dan Lubis yang sudah tervalidasi, terdiri dari sembilan pertanyaan pola asuh pemberian makan dan sebelas pertanyaan pola asuh perawatan kesehatan dasar ${ }^{19,20}$. Pertanyaan pola asuh pemberian makan pada balita meliputi pemberian kolostrum, pemberian ASI eksklusif, pemberian MP-ASI < 6 bulan dan $>6$ bulan, kebiasaan makan 3x/hari, kebiasaan makan sendiri, kebiasaan konsumsi sayur dan buah, menyuapi dan membujuk anak jika tidak nafsu makan dan anak selalu menghabiskan makanan. Pertanyaan untuk pola asuh perawatan kesehatan dasar pada balita meliputi imunisasi dan kelengkapannya, penimbangan posyandu setiap bulan, kebiasaan ibu dan anak untuk cuci tangan dengan sabun sebelum dan sesudah makan, memeriksa dan menggunting kuku anak seminggu sekali, tidak membiarkan anak bermain di tempat yang kotor, mencuci rambut anak minimal $1 \mathrm{x} /$ minggu, mengingatkan anak mencuci kaki dan menggosok gigi sebelum tidur, membiasakan mandi $2 x /$ hari dan membiasakan mengganti pakaian anak setelah bermain diluar. Terdapat tiga kemungkinan jawaban yaitu ya (skor 3), kadang (skor 2) dan tidak (skor 1), masing-masing pola asuh diklasifikasikan menjadi kurang $(<60 \%)$, sedang $(60$ $80 \%$ ) dan baik $(>80 \%)^{21}$. SQ-FFQ balita diteliti dalam tiga bulan terakhir, terdiri dari 35 jenis makanan yang merupakan sumber karbohidrat, protein, vitamin A dan seng. Jenis makanan tersebut disesuaikan dengan makanan yang biasa dikonsumsi masyarakat Kecamatan Gending, namun belum dilakukan validasi kuesioner SQFFQ. Data SQ-FFQ diolah menggunakan software Nutrisurvey dengan memasukkan jumlah masing-masing jenis makanan per balita, sehingga asupan energi, protein, seng dan vitamin A dapat diketahui. Asupan energi dan protein dibandingkan dengan Angka Kecukupan Gizi (AKG) masing-masing zat gizi. Kemudian diklasifikasikan menjadi kurang jika tingkat kecukupan zat gizi $<77 \%$ nilai AKG dan cukup jika tingkat kecukupan zat gizi $\geq 77 \%$ nilai AKG. Asupan seng dan vitamin A dibandingkan dengan Estimated Average Requirements (EAR) masing-masing zat gizi, selanjutnya dikasifikasikan menjadi kurang jika tingkat kecukupan zat gizi $<E A R$ dan cukup jika tingkat kecukupan zat gizi $\geq E^{22}$. Data sekunder penelitian merupakan gambaran umum dan data balita stunting maupun non-stunting dari Puskesmas Gending dan Posyandu Desa Pajurangan.

Analisis yang digunakan adalah uji chi square dengan melihat Odds Ratio (OR) atau besar risiko antara variabel independen dengan variabel dependen. Penelitian ini telah mendapatkan persetujuan etik dari Komisi Etik Penelitian Kesehatan (KEPK) Fakultas Kesehatan Masyarakat Universitas Airlangga dengan nomor 170/EA/KEPK/2019.

\section{HASILDAN PEMBAHASAN}

\section{Karakteristik Responden}

Karakteristik responden (ibu) meliputi usia dan pendidikan, didapatkan melalui wawancara kuesioner. Hasil penelitian dapat dilihat pada Tabel 1, sebagian besar usia ibu pada kelompok balita stunting dan non 
stunting pada kategori dewasa awal masing-masing sebesar $56,5 \%$ dan $43,5 \%$. Usia yang bertambah akan mematangkan cara berpikir, sehingga berkorelasi dengan terjadinya peningkatan pengetahuan dan pengalaman yang didapat ${ }^{23}$.

Berdasarkan Tabel 1 menunjukkan bahwa tingkat pendidikan ibu yang memiliki balita stunting tertinggi pada kategori dasar atau tamatan SD/SMP sederajat (56,5\%). Tingkat pendidikan ibu yang memiliki balita non stunting tertinggi pada kelompok menengah atau tamatan SMA sederajat yaitu 39,1\%.Pendidikan dapat mempengaruhi kemampuan ibu dalam mengetahui dan menerapkan hal tertentu seperti pola asuh. Ibu yang berpendidikan lebih tinggi umumnya dapat memilih makanan yang lebih baik mutu dan jumlahnya ${ }^{24}$. Hal tersebut tentunya akan mempengaruhi kecukupan asupan yang dikonsumsi, sehingga akan mempengaruhi status gizi balita. Ibu yang berpendidikan rendah lebih berisiko memiliki balita stunting dibandingkan yang tidak $^{25}$.

Tabel 1. Karakteristik Responden, Keluarga dan Balita

\begin{tabular}{|c|c|c|c|c|}
\hline \multirow{2}{*}{ Karakteristik Responden, Keluarga dan Balita } & \multicolumn{2}{|c|}{ Stunting } & \multicolumn{2}{|c|}{ Non Stunting } \\
\hline & $\mathrm{n}$ & $\%$ & $\mathrm{n}$ & $\%$ \\
\hline \multicolumn{5}{|l|}{ Usia Ibu } \\
\hline Remaja akhir (17-25 tahun) & 6 & 26,1 & 6 & 26,1 \\
\hline Dewasa awal (26-35 tahun) & 13 & 56,5 & 10 & 43,5 \\
\hline Dewasa akhir (36-45 tahun) & 4 & 17,4 & 6 & 26,1 \\
\hline Lansia Awal (46-55 tahun) & 0 & 0 & 1 & 4,3 \\
\hline \multicolumn{5}{|l|}{ Pendidikan Ibu } \\
\hline Dasar (SD/SMP/sederajat) & 13 & 56,5 & 7 & 30,4 \\
\hline Menengah (SMA/sederajat) & 8 & 34,8 & 9 & 39,1 \\
\hline Tinggi (perguruan tinggi) & 2 & 8,7 & 7 & 30,4 \\
\hline \multicolumn{5}{|l|}{ Pekerjaan Ayah } \\
\hline Tidak Bekerja & 0 & 0 & 0 & 0 \\
\hline Wiraswasta & 1 & 4,3 & 0 & 0 \\
\hline Petani/Buruh & 10 & 43,5 & 8 & 34,8 \\
\hline Pegawai & 6 & 26,1 & 5 & 21,7 \\
\hline Nelayan & 6 & 26,1 & 10 & 43,5 \\
\hline Lainnya & 0 & 0 & 0 & 0 \\
\hline \multicolumn{5}{|l|}{ Pekerjaan Ibu } \\
\hline Tidak Bekerja & 17 & 73,9 & 12 & 52,2 \\
\hline Wiraswasta & 1 & 4,3 & 2 & 8,7 \\
\hline Petani/Buruh & 0 & 0 & 1 & 4,3 \\
\hline Pegawai & 4 & 17,5 & 6 & 26,1 \\
\hline Nelayan & 0 & 0 & 0 & 0 \\
\hline Lainnya & 1 & 4,3 & 2 & 8,7 \\
\hline \multicolumn{5}{|l|}{ Pendapatan Keluarga } \\
\hline Kuartil 1 (Rp 500.000-Rp 1.375.000) & 10 & 43,5 & 7 & 30,5 \\
\hline Kuartil 2 (>Rp 1.375.000-Rp 2.250.000) & 8 & 34,8 & 12 & 52,2 \\
\hline Kuartil 3 (>Rp 2.250.000-Rp 3.125.000) & 4 & 17,4 & 3 & 13 \\
\hline Kuartil 4 (>Rp 3.125.000-Rp 4.000.000) & 1 & 4,3 & 1 & 4,3 \\
\hline \multicolumn{5}{|l|}{ Usia Balita } \\
\hline 24-47 bulan & 12 & 52,2 & 12 & 52,2 \\
\hline $48-60$ bulan & 11 & 47,8 & 11 & 47,8 \\
\hline \multicolumn{5}{|l|}{ Jenis Kelamin Balita } \\
\hline Laki-laki & 12 & 52,2 & 11 & 47,8 \\
\hline Perempuan & 11 & 47,8 & 12 & 52,2 \\
\hline
\end{tabular}

\section{Karakteristik Keluarga}

Karakteristik keluarga meliputi pekerjaan dan pendapatan orang tua, diperoleh melalui wawancara menggunakan kuesioner. Berdasarkan Tabel 1 pekerjaan ayah pada balita stunting tertinggi pada kelompok petani/buruh dengan persentase $43,5 \%$, sedangkan pada balita non stunting tertinggi pada kelompok nelayan dengan persentase $43,5 \%$. Kemudian pekerjaan ibu pada balita stunting dan non stunting tertinggi pada kelompok tidak bekerja atau sebagai ibu rumah tangga dengan persentase berturut-turut $73,9 \%$ dan $52,2 \%$.Ayah yang bekerja sebagai nelayan dapat membawa hasil tangkapan ikannya ke rumah untuk dikonsumsi sendiri, sehingga balita sering mengkonsumsi ikan-ikanan. Jenis ikan dan hasil laut lainnya kisaran harganya bervariasi di pasaran, terkadang hal itulah yang mempengaruhi daya beli masyarakat. Oleh karena itu status ekonomi rumah tangga mempengaruhi konsumsi pangan dan status gizi masyarakat $^{24}$.

Pendapatan keluarga merupakan penghasilan 
yang dihasilkan oleh ayah dan ibu berdasarkan jenis pekerjaan yang dijalani, menggunakan kuesioner dengan jawaban terbuka kemudian diklasifikasikan berdasarkan kuartil. Berdasarkan Tabel 1 pendapatan keluarga yang memiliki balita stunting paling banyak menduduki kuartil 1 (Rp 500.000-Rp 1.375.000) dengan persentase 43,5\%, sedangkan pendapatan keluarga yang memiliki balita non stunting paling banyak menduduki kuartil 2 (>Rp 1.375.000-Rp 2.250.000) dengan persentase $52,2 \%$. Walaupun terdapat perbedaan kuartil, kedua kelompok masih berada dibawah UMK Kabupaten Probolinggo tahun 2019 ( $\operatorname{Rp~2.306.944,93).~Besarnya~pendapatan~}$ dapat mempengaruhi akses dan kemampuan daya beli bahan makanan, sehingga terbentuk ketersediaan pangan keluarga. Meningkatnya pendapatan memberikan kesempatan bagi keluarga untuk membeli pangan dengan kualitas dan kuantitas yang lebih baik, sebaliknya jika pendapatan menurun akan terjadi penurunan daya beli bahan pangan dengan kualitas dan kuantitas yang rendah ${ }^{26}$.

\section{Karakteristik Balita}

Karakteristik balita terdiri dari usia dan jenis kelamin. Usia balita atau subjek didapatkan melalui wawancara kuesioner dan melihat buku KMS. Berdasarkan Tabel 1, diketahui usia balita kedua kelompok sama-sama lebih banyak pada kategori 24-47 bulan yaitu sebesar $52,2 \%$. Permasalahan stunting dapat terjadi mulai 1.000 hari pertama kehidupan (HPK) atau kurang dari dua tahun, karena pertumbuhan balita yang terjadi pada usia tersebut merupakan masa kritis dan sensitif yang dapat menyebabkan masalah gizi kronis seperti stunting di masa yang akan datang jika tidak segera ditangani ${ }^{27}$. Walaupun begitu permasalahan stunting dapat dilihat pada usia dua tahun ke atas, karena pada usia tersebut permasalahan stunting bersifat tidak mungkin reversible ${ }^{5,28}$. Oleh karena itu pola asuh dan tingkat kecukupan zat gizi dapat mempengaruhi kejadian stunting. Pola asuh dalam penelitian ini dimulai dari $1.000 \mathrm{HPK}$, kegagalan pola asuh pada 1.000 HPK secara terus-menerus seperti pemberian ASI tidak ekslusif, MP-ASI dini dan perawatan kesehatan balita yang kurang baik berisiko mengalami permasalahan stunting. Begitu juga dengan tingkat kecukupan zat gizi yang kurang pada balita dalam beberapa bulan terakhir dapat menyebabkan stunting. Jenis kelamin balita terdiri dari laki-laki dan perempuan. Tabel 1 menunjukkan bahwa pada kelompok stunting lebih banyak terjadi pada balita laki-laki, sedangkan kelompok non stunting lebih banyak terjadi pada balita perempuan masing-masing sebesar $52,2 \%$.

Tabel 2. Distribusi dan Hasil Uji Perbedaan Pola Asuh pada Balita Stunting dan Non-Stunting di Wilayah Pesisir

\begin{tabular}{|c|c|c|c|c|c|c|c|c|}
\hline \multirow{2}{*}{ Variabel Pola Asuh } & \multicolumn{2}{|c|}{ Stunting } & \multicolumn{2}{|c|}{ Non Stunting } & \multicolumn{2}{|c|}{ Jumlah } & \multirow{2}{*}{$p$-value } & \multirow{2}{*}{$\begin{array}{c}\text { OR } \\
(95 \% \mathrm{Cl})\end{array}$} \\
\hline & $\mathrm{n}$ & $\%$ & $\mathrm{n}$ & $\%$ & $\mathrm{~N}$ & $\%$ & & \\
\hline \multicolumn{9}{|c|}{ Pola Asuh Pemberian Makan } \\
\hline Kurang $(<60 \%)$ & 0 & 0 & 0 & 0 & 0 & 0 & $0,002 *$ & 10,37 \\
\hline Sedang $(60 \%-80 \%)$ & 14 & 60,9 & 3 & 13 & 17 & 37 & & $(2,374-45,301)$ \\
\hline Baik (> 80\%) & 9 & 39,1 & 20 & 87 & 29 & 63 & & \\
\hline \multicolumn{9}{|c|}{ Pola Asuh Perawatan Kesehatan Dasar } \\
\hline Kurang $(<60 \%)$ & 0 & 0 & 0 & 0 & 0 & 0 & 0,662 & - \\
\hline Sedang $(60 \%-80 \%)$ & 2 & 8,7 & 4 & 17,4 & 6 & 13 & & \\
\hline Baik (> 80\%) & 21 & 91,3 & 19 & 82,6 & 40 & 87 & & \\
\hline
\end{tabular}

*signifikan $p$-value $<0,05$

\section{Perbedaan Antar Variabel}

Pola asuh pemberian makan diperoleh melalui wawancara kuesioner. Berdasarkan Tabel 2 sebagian besar kelompok stunting memiliki pola asuh pemberian makan dengan kategori sedang $(60,9 \%)$. Berbeda dengan sebagian besar kelompok non stunting, pola asuh pemberian makannya kategori baik dengan persentase $87 \%$. Oleh karena itu terdapat perbedaan pola asuh pemberian makan pada kelompok balita stunting dan non stunting di wilayah pesisir Kabupaten Probolinggo $(p=0,002)$ dengan $O R \quad 10,37$, artinya ibu dengan pola asuh pemberian makan kategori sedang memiliki risiko 10,37 kali lebih besar balitanya mengalami stunting dibandingkan pola asuh pemberian makan yang baik. Pola asuh pemberian makan yang cenderung dilakukan responden kelompok balita stunting adalah pemberian
ASI yang tidak eksklusif (ada penambahan susu formula) dan MP-ASI dini, selain itu jumlah asupan cenderung kurang. Berbeda dengan responden yang memiliki balita non stunting memberikan ASI eksklusif dan MP-ASI cukup umur sehingga rata-rata asupan zat gizi terpenuhi. Hasil penelitian ini sejalan dengan penelitian Pratiwi dkk yang menyatakan bahwa terdapat hubungan yang bermakna antara pola asuh makan dan status gizi ${ }^{29}$. Begitu juga dengan Rahmayana dkk menyatakan bahwa terdapat hubungan pola asuh dengan kejadian stunting ${ }^{5}$. Ibu berperan dalam menyiapkan kebutuhan pangan sebelum anak lahir ke dunia, mulai dari pranikah dengan memperhatikan gizi sebelum hamil, masa prenatal dan masa neonatal berupa pemberian ASI, persiapan makanan tambahan atau pendamping (makanan padat yang lebih bervariasi bahannya) dan kasih sayang untuk 
$a k^{4}$. Pola asuh pemberian makan yang salah seperti ASI tidak eksklusif dan pemberian MP-ASI dini akan mempengaruhi kecukupan asupan yang dikonsumsi. Hal tersebut berdampak dalam proses pertumbuhan balita sehingga muncul masalah stunting.

Berdasarkan hasil wawancara pola asuh perawatan kesehatan dasar kepada responden didapatkan bahwa tidak terdapat perbedaan pola asuh perawatan kesehatan dasar pada kelompok balita stunting dan non stunting di wilayah pesisir Kabupaten Probolinggo $(p=0,662)$. Hal tersebut dapat dilihat pada Tabel 2, sebagian besar kelompok stunting dan non stunting memiliki pola asuh perawatan kesehatan dasar kategori baik dengan persentase berturut-turut 91,3\% dan $82,6 \%$.Selain itu sebagian besar kedua kelompok responden rutin ke posyandu untuk melakukan penimbangan dan imunisasi lengkap serta terbiasa melakukan Perilaku Hidup Bersih dan Sehat (PHBS) terhadap keluarganya, sehingga pola asuh perawatan kesehatan dasar cenderung kategori baik. Hasil penelitian ini sejalan dengan penelitian Noviyana dan Purwatis bahwa tidak terdapat hubungan antara pola asuh perawatan kesehatan dengan status gizi ${ }^{30}$. Perawatan kesehatan dasar anak meliputi memperhatikan keadaan gizi, melakukan penimbangan dan imunisasi anak, menjaga kebersihan diri anak, menjaga kondisi perumahan dan sanitasi lingkungan, mencari pengobatan ketika anak sakit dan stimulasi untuk anak ${ }^{4}$. Jika pola asuh perawatan kesehatan dasar tidak diterapkan dengan baik, balita akan lebih mudah sakit dan terkena infeksi berulang. Infeksi berulang akan menghambat pertumbuhan balita, dampaknya balita dapat mengalami stunting.

Tabel 3 menunjukkan bahwa rata-rata asupan zat gizi untuk kelompok stunting meliputi energi 840,99 kkal; protein 21,19 g; vitamin A 243,60 $\mu \mathrm{g}$ dan seng 2,91 mg. Rata-rata asupan zat gizi pada kelompok non stunting meliputi energi 1063,24 kkal; protein 27,53 g; vitamin A 387,04 $\mu$ g dan seng 3,64 mg. Hal tersebut menunjukkan bahwa asupan zat gizi kelompok balita stunting masih dibawah kelompok balita non stunting. Asupan zat gizi tersebut dibandingkan dengan AKG untuk makronutrien dan EAR untuk mikronutrien.

Tabel 3. Distribusi Asupan Zat Gizi pada Balita Stunting dan Non-Stunting

\begin{tabular}{lcccccc}
\hline \multirow{2}{*}{ Jumlah Asupan } & \multicolumn{3}{c}{ Stunting } & \multicolumn{3}{c}{ Non Stunting } \\
\cline { 2 - 7 } & $\bar{x} \pm$ SD & Min & Max & $\bar{x} \pm$ SD & Min & Max \\
\hline Energi (kkal) & $840,99 \pm 260,24$ & 414,1 & 1349,1 & $1063,24 \pm 213,3$ & 728,3 & 1393,8 \\
Protein (g) & $21,19 \pm 4,55$ & 12,6 & 27,6 & $27,53 \pm 5,03$ & 19,8 & 36,4 \\
Vitamin A ( $\mu \mathrm{g})$ & $243,60 \pm 88,75$ & 102,8 & 472,3 & $387,04 \pm 138,3$ & 127,9 & 607,1 \\
Seng $(\mathrm{mg})$ & $2,91 \pm 0,93$ & 1,5 & 4,8 & $3,64 \pm 0,696$ & 2,2 & 4,7 \\
\hline
\end{tabular}

Hasil penelitian pada Tabel 4 menunjukkan bahwa sebagian besar kelompok stunting memiliki tingkat kecukupan energi $(60,9 \%)$ yang kurang, sedangkan kelompok non-stunting memiliki tingkat kecukupan energi $(73,9 \%)$ yang cukup. Oleh karena itu, terdapat perbedaan tingkat kecukupan energi $(p=0,037)$ pada kelompok balita stunting dan non stunting di wilayah pesisir Kabupaten Probolinggo dengan OR 4,407. Analisis risiko tersebut artinya balita dengan tingkat kecukupan energi kurang memiliki risiko 4,407 kali lebih besar mengalami stunting dibandingkan tingkat kecukupan energi yang cukup.Begitu pula dengan protein, sebagian besar kelompok stunting memiliki tingkat kecukupan protein $(65,2 \%)$ yang kurang. Kelompok non-stunting memiliki tingkat kecukupan protein (87\%) yang cukup. Terdapat perbedaan tingkat kecukupan protein $(p=0,001)$ pada kelompok balita stunting dan non stunting di wilayah pesisir Kabupaten Probolinggo dengan OR 12,5, artinya tingkat kecukupan protein yang kurang pada balita akan berisiko 12,5 kali lebih besar mengalami stunting dibanding tingkat kecukupan protein yang cukup. Berbeda halnya dengan tingkat kecukupan vitamin A bahwa sebagian besar kelompok stunting dan non stunting memiliki tingkat kecukupan vitamin A yang cukup dengan persentase berturut-turut $65,2 \%$ dan $82,6 \%$, sehingga tidak terdapat perbedaan pada kelompok balita stunting dan non stunting di wilayah pesisir Kabupaten Probolinggo $(p=0,314)$.Tingkat kecukupan seng pada kelompok stunting kurang $(56,5 \%)$, sedangkan pada kelompok nonstunting cukup $(82,6 \%)$. Oleh karena itu terdapat perbedaan tingkat kecukupan seng $(p=0,015)$ pada kelompok balita stunting dan non stunting di wilayah pesisir Kabupaten Probolinggo dengan OR 6,175, artinya balita dengan tingkat kecukupan seng kurang memiliki risiko 6,175 kali lebih besar mengalami stunting dibandingkan balita dengan tingkat kecukupan seng yang cukup.

Sebagian besar balita stunting mengkonsumsi nasi hanya setengah centong nasi ( \pm 30 gram), jarang mengkonsumsi daging karena harga yang terlalu mahal, jarang mengkonsumsi ikan bahkan makanan laut seperti kepiting, udang, cumi-cumi karena harga cenderung mahal. Lauk hewani yang sering dikonsumsi adalah telur dan ayam. Tidak menyukai beberapa jenis sayur, biasanya hanya nasi dengan kuah sayur saja. Adapun sayur yang sering dikonsumsi yaitu sayur kelor 1-2 kali 
per bulan. Konsumsi buah juga jarang karena harga yang mahal dan faktor pendapatan keluarga yang rendah. Berbeda halnya dengan balita non stunting sebagian besar konsumsi nasi minimal satu centong nasi $( \pm 60$ gram) bahkan terdapat beberapa balita yang mengkonsumsi lebih dari satu centong nasi. Responden memberikan lauk hewani seperti ayam, daging (tidak terlalu sering, 2-3 kali per bulan), hati ayam dan sapi, ikan dan makanan laut lainnya (hasil tangkapan sendiri) serta telur kepada balitanya. Balita dikenalkan dan dibiasakan mengkonsumsi sayuran, adapun sayuran yang paling disukai dan sering dikonsumsi adalah sayur kelor. Konsumsi buah-buahan sebagian besar adalah pisang. Kedua kelompok balita menyukai konsumsi susu baik formula maupun kemasan sachet, bahkan setiap hari mengkonsumsinya minimal sekali. Hal tersebut yang menyebabkan tingkat kecukupan vitamin A sudah tercukupi. Selain itu beberapa balita dari kedua kelompok mengkonsumsi hati ayam dan sapi yang juga menjadi sumber vitamin $A$.

Tabel 4. Distribusi dan Hasil Uji Perbedaan Tingkat Kecukupan Zat Gizi pada Balita Stunting dan Non-Stunting di Wilayah Pesisir

\begin{tabular}{|c|c|c|c|c|c|c|c|c|}
\hline \multirow{2}{*}{ Tingkat Kecukupan } & \multicolumn{2}{|c|}{ Stunting } & \multicolumn{2}{|c|}{ Non Stunting } & \multicolumn{2}{|c|}{ Jumlah } & \multirow{2}{*}{$p$-value } & \multirow{2}{*}{$\begin{array}{c}\text { OR } \\
(95 \% \mathrm{Cl})\end{array}$} \\
\hline & $\mathrm{n}$ & $\%$ & $\mathrm{n}$ & $\%$ & $\mathrm{~N}$ & $\%$ & & \\
\hline \multicolumn{9}{|l|}{ Energi } \\
\hline Kurang (< 77\% AKG) & 14 & 60,9 & 6 & 26,1 & 20 & 43,5 & $0,037^{*}$ & 4,407 \\
\hline Cukup ( $\geq 77 \%$ AKG) & 9 & 39,1 & 17 & 73,9 & 26 & 56,5 & & $(1,26-15,414)$ \\
\hline \multicolumn{9}{|l|}{ Protein } \\
\hline Kurang(< 77\% AKG) & 15 & 65,2 & 3 & 13 & 18 & 39,1 & $0,001^{*}$ & 12,50 \\
\hline Cukup ( $\geq 77 \%$ AKG) & 8 & 34,8 & 20 & 87 & 28 & 60,9 & & $(2,828-55,254)$ \\
\hline \multicolumn{9}{|l|}{ Vitamin A } \\
\hline Kurang (<EAR) & 8 & 34,8 & 4 & 17,4 & 12 & 26,1 & 0,314 & - \\
\hline Cukup ( $\geq E A R$ ) & 15 & 65,2 & 19 & 82,6 & 34 & 73,9 & & \\
\hline \multicolumn{9}{|l|}{ Seng } \\
\hline Kurang (< EAR) & 13 & 56,5 & 4 & 17,4 & 17 & 37 & $0,015^{*}$ & 6,175 \\
\hline Cukup ( $\geq$ EAR) & 10 & 43,5 & 19 & 82,6 & 29 & 63 & & $(1,589-23,993)$ \\
\hline
\end{tabular}

*Signifikan $p$-value $<0,05$

Hasil penelitian ini sejalan dengan penelitian Damayanti dkk bahwa terdapat perbedaan tingkat kecukupan energi, protein dan seng pada balita stunting dan non stunting di Kelurahan Kejawan Putih Tambak Surabaya $^{31}$. Penelitian terkait tingkat kecukupan vitamin A tidak sejalan dengan penelitian Fatimah dan Wirjatmadi yang menjelaskan bahwa terdapat perbedaan tingkat kecukupan vitamin A yang bermakna pada balita stunting dan non stunting ${ }^{32}$.

Status gizi balita dapat dilihat dari tingkat konsumsi menurut kualitas dan kuantitas hidangan yang tersedia dalam keluarga. Susunan hidangan yang memenuhi kebutuhan tubuh dari segi kualitas dan kuantitas, maka kondisi kesehatan gizi anak akan baik. Konsumsi yang adekuat memberi pengaruh terhadap peningkatan kesehatan gizi. Konsumsi yang baik namun dalam jumlah lebih dari kebutuhan tubuh akan mengakibatkan konsumsi berlebih, sehingga dapat memicu terjadinya masalah gizi lebih. Sebaliknya jika konsumsi kurang baik dari segi kualitas maupun kuantitas akan menyebabkan masalah gizi kurang atau keadaan defisiensi ${ }^{24}$. Energi yang tidak tercukupi dapat memicu kekurangan energi kronis (KEK), jika tidak segera ditangani akan berdampak pada terganggunya pertumbuhan linier ${ }^{33}$. Begitu pula dengan protein, merupakan reseptor untuk DNA yang mengatur proses pertumbuhan. Terjadi kerusakan massa mineral jika asupan protein kurang, yaitu melalui kerusakan produksi Insuline-like Growth Factor 1 (IGF-1) sehingga berdampak pada terganggunya osteoblas ${ }^{34}$. Hal tersebut yang menyebabkan pertumbuhan linier terganggu dan dapat menyebabkan terjadinya stunting. Defisiensi seng mempengaruhi hormon pertumbuhan seperti IGF-1, Growth Hormone (GH) reseptor dan GH Binding Protein mRNA di dalam tubuh menjadi rendah. Sistem regulasi hormon pertumbuhan yang rendah mampu menghambat pertumbuhan linear. Walaupun kebutuhannya sedikit, namun seng berperan penting dalam pencegahan stunting. Vitamin A juga memiliki peran penting dalam pencegahan stunting. Derivat vitamin A yaitu asam retinoat mempengaruhi hormon lain yang mengontrol pertumbuhan jaringan skeletal ${ }^{24}$. Kebiasaan konsumsi makanan sehari-hari yang tidak tepat dan tercukupi dalam kurun waktu tertentu dapat menyebabkan masalah gizi kurang. Masalah gizi kurang yang berkepanjangan akan menimbulkan kejadian stunting. Penelitian ini memiliki kelemahan yaitu tidak melakukan validasi kuesioner SQ-FFQ balita, sehingga memungkinkan adanya jenis makanan yang tidak banyak dikonsumsi oleh subjek pada kuesioner. Saran untuk penelitian selanjutnya adalah melakukan validasi jenis makanan di daerah yang akan diteliti agar dapat menunjukkan kebiasaan makan balita secara terperinci di daerah tersebut.

\section{KESIMPULAN}

Hasil penelitian menunjukkan pola asuh pemberian makan kategori sedang berisiko 10,37 kali lebih besar balitanya mengalami stunting dibanding pola asuh pemberian makan kategori baik. Tingkat kecukupan energi protein dan seng yang rendah pada balita memilki risiko masing-masing sebesar 4,407, 12,5 dan 6,175 kali mengalami stunting. Adapun pola asuh perawatan kesehatan dasar dan tingkat kecukupan vitamin A pada 
balita stunting dan non stunting tidak terdapat perbedaan.

\section{ACKNOWLEDGEMENT}

Ucapan terimakasih disampaikan kepada pihak Puskesmas Gending Kabupaten Probolinggo yang telah memberikan ijin penelitian di Desa Pajurangan, kepada kader posyandu Desa Pajurangan Kabupaten Probolinggo yang telah membantu penelitian dalam pencarian responden dan kepada ibu balita yang telah bersedia menjadi responden penelitian.

\section{REFERENSI}

1. Harjatmo, T., Par'i, H. \& Wiyono, S. Penilaian Status Gizi. (Kementerian Kesehatan Republik Indonesia, 2017).

2. R.I., K. K. Pemantauan Status Gizi Tahun 2017. (Ditjen. Kesehatan Masyarakat, 2018).

3. Kementerian Desa Pembangunan Daerah Tertinggal dan Transmigrasi. Buku saku desa dalam penanganan stunting. Buku Saku Desa Dalam Penanganan Stunting 2-13 (2017).

4. Soetjiningsih. Tumbuh Kembang Anak. (EGC, 2012).

5. Rahmayana, Ibrahim, I. \& Damayanti, D. Hubungan Pola Asuh dengan Kejadian Stunting Anak Usia 24-59 Bulan di Posyandu Asoka II Wilayah Pesisir Kelurahan Barombong Kecamatan Tamalate Kota Makassar Tahun 2014. (Universitas Islam Negeri Alauddin Makassar, 2014).

6. Leo, A. R., Subagyo, H. W. \& Kartasurya, M. I. FAKTOR RISIKO STUNTING PADA ANAK USIA 2-5 TAHUN DI WILAYAH GUNUNG DAN PESISIR PANTAI Risk Factors of Stunting among Children Aged 2-5 Years in Ridge And Coastal kerja Puskesmas Oelbiteno Kecamatan. J. Gipas 2 , (2018).

7. Picauly, I., Sarci, D. \& Toy, M. ANALISIS DETERMINAN DAN PENGARUH STUNTING TERHADAP PRESTASI BELAJAR ANAK SEKOLAH DI KUPANG DAN SUMBA TIMUR, NTT (The Determinant Analysis and the Impact of Stunting for School Children School Performance in Kupang and Sumba Timur, NTT). J. Gizi dan Pangan, 8, 55-62 (2013).

8. Anindita, P. Hubungan Tingkat Pendidikan Ibu, Pendapatan Keluarga, Kecukupan Protein \& Zinc Dengan Stunting (Pendek) Pada Balita Usia 6 35 Bulan Di Kecamatan Tembalang Kota Semarang. J. Kesehat. Masy. 1, 1-10 (2012).

9. Mikhail, Z. A., Sobhy, H. M. \& ElSayed, H. . Effect of Nutritional Status on Growth Pattern of Stunted Preschool Children in Egypt. Acad. J. Nutr. 2, 1-09 (2013).

10. RI, K. K. Riset Kesehatan Dasar (Riskesdas) 2013. (Badan Penelitian dan Pengembangan Kesehatan, 2013).

11. RI, K. K. Hasil Utama Riskesdas 2018. (Penelitian dan Pengembangan Kesehatan, 2018).
12. WHO. WHO global database on child growth and malnutrition. (World Health Organization, 1997).

13. R.I., K. K. Buku Saku Pemantauan Status Gizi Tahun 2016. (Ditjen. Kesehatan Masyarakat, 2017).

14. Kementerian, K. Pemantauan Status Gizi Tahun 2017. (Ditjen. Kesehatan Masyarakat, 2018).

15. Probolinggo, D. K. K. Hasil Bulan Timbang Februari 2018. (Bidang Kesehatan Keluarga dan Gizi, 2018).

16. Firmansyah \& Farhan, M. Analisis Pola Konsumsi Daging Sapi pada Masyarakat Pesisir di Kabupaten Tanjung Jabung Timur. J. IImu-IImu Peternak. 17, 62-69 (2014).

17. Gending, P. Laporan Hasil Kegiatan Bulan Timbang Agustus Tahun 2018. (Bidang Gizi, 2018).

18. Lemeshow, S., Hosmer, D., Klar, J. \& Lwanga, S. Adequacy of Sample Size in Health Studies. (John Wiley Sons Ltd, 1990).

19. Adelina, M. Hubungan Pengetahuan Gizi dan 1000 HPK Ibu serta Pola Asuh dengan Status Gizi Balita (BB/U) di Kecamatan Jasinga Kabupaten Bogor. (Institut Pertanian Bogor, 2018).

20. Lubis, R. Hubungan Pola Asuh Ibu dengan Status Gizi Anak Balita di Wilayah Kerja Puskesmas Pantai Cermin Kecamatan Tanjung Pura Kabupaten Langkat Tahun 2008. (Universitas Sumatra Utara, 2008).

21. Ulfa, M. \& Latifah, M. Hubungan pola asuh makan, pengetahuan gizi, presepsi dengan kebiasaan makan sayuran ibu rumah tangga di perkotaan dan pedesaan Bogor. Media Gizi dan Kel. 31, 30-41 (2007).

22. Gibson, R. S. Principles of Nutritional Assessment. (Oxford University Press, 2005).

23. Wawan, A. \& Dewi, M. Teori Pengukuran Pengetahuan, Sikap dan Perilaku Manusia. (Nuha Medika, 2010).

24. Adriani, M. \& Wirjatmadi, B. Gizi dan Kesehatan Balita Peranan Mikro Zinc pada Pertumbuhan Balita. (Kencana, 2014).

25. Fajrina, N. Hubungan Faktor Ibu dengan Kejadian Stunting pada Balita di Puskesmas Piyungan Kabupaten Bantul. (Universitas Aisyiyah Yogyakarta, 2016).

26. Sulistyoningsih, H. Gizi untuk Kesehatan Ibu dan Anak. Yogyakarta: Graha Ilmu. (2011).

27. Altare, C., Delbiso, T. D., Mutwiri, G. M., Kopplow, R. \& Guha-Sapir, D. Factors associated with stunting among pre-school children in southern highlands of Tanzania. J. Trop. Pediatr. 62, 390-408 (2016).

28. TNP2K. 100 Kabupaten/Kota Prioritas untuk Intervensi Anak kerdil (Stunting). (Tim Nasional Percepatan Penanggulangan Kemiskinan, 2017).

29. Pratiwi T. D. , Masrul, Y. E. Hubungan pola asuh ibu dengan status gizi balita di wilayah kerja Puskesmas Belimbing Kota Padang. J. Kesehat. Andalas 5, 661-665 (2016).

30. Noviyana, A. \& Purwatis. Pola Asuh 
Hubungannya dengan Status Gizi Batita di Desa Sokawera Wilayah Kerja Puskesmas Patikraja Banyumas. in jurnal Temu Ilmiah Hasil

Penelitian dan Pengabdian Masyarakat. (2016).

31. Damayanti, R. A., Muniroh, L. \& Farapti. Pemberian Asi Eksklusif Pada Balita Stunting Dan NonStunting. Media Gizi Indones. 11, 61-69 (2016).

32. Fatimah, N. S. H. \& Wirjatmadi, B. Tingkat Kecukupan Vitamin a, Seng Dan Zat Besi Serta Frekuensi Infeksi Pada Balita Stunting Dan Non
Stunting. Media Gizi Indones. 13, 168 (2018).

33. Adani, F. \& Nindya, T. Perbedaan Asupan Energi, Protein, Zink, dan Perkembangan pada Balita Stunting dan non Stunting. Amerta Nutr. 1, 4651 (2017).

34. Sari, E., Juffrie, M., Nurani, N. \& Sitaresmi, M. Protein, calcium and phosphorus intake of stunting and non stunting children aged 24-59 months. J. Gizi Klin. Indones. 12, 152-159 (2016). 